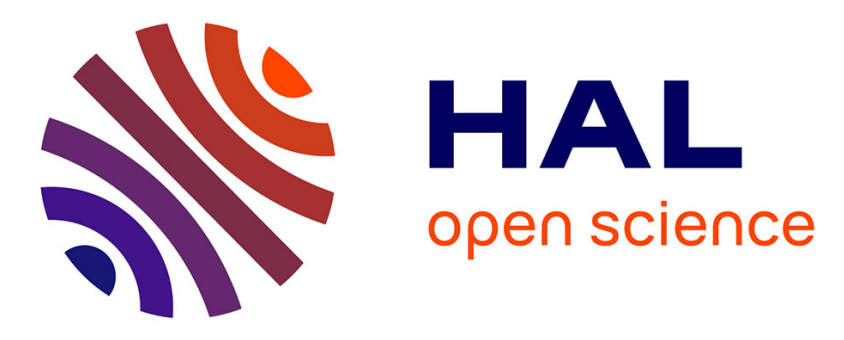

\title{
Contribution of situational operational leeway for ergonomic assessment in the evaluation of work situations
}

Maxime Norval, Mohsen Zare, René Brunet, Fabien Coutarel, Yves Roquelaure

\section{To cite this version:}

Maxime Norval, Mohsen Zare, René Brunet, Fabien Coutarel, Yves Roquelaure. Contribution of situational operational leeway for ergonomic assessment in the evaluation of work situations. Theoretical Issues in Ergonomics Science, 2021, 22 (2), pp.139-160. 10.1080/1463922X.2020.1785039 . halshs-02919783

\section{HAL Id: halshs-02919783 \\ https://shs.hal.science/halshs-02919783}

Submitted on 11 Sep 2020

HAL is a multi-disciplinary open access archive for the deposit and dissemination of scientific research documents, whether they are published or not. The documents may come from teaching and research institutions in France or abroad, or from public or private research centers.
L'archive ouverte pluridisciplinaire HAL, est destinée au dépôt et à la diffusion de documents scientifiques de niveau recherche, publiés ou non, émanant des établissements d'enseignement et de recherche français ou étrangers, des laboratoires publics ou privés. 


\title{
Original Article
}

\section{Contribution of Situational Operational Leeway for Ergonomic Assessment in the Evaluation of Work Situations}

\author{
Maxime Norval ${ }^{\mathrm{a}}$, Mohsen Zare ${ }^{\mathrm{b} *}$, René Brunet ${ }^{\mathrm{a}}$, Fabien Coutarel $^{\mathrm{c}}$, and \\ Yves Roquelaure \\ ${ }^{a}$ Univ Angers, CHU Angers, Univ Rennes, Inserm, Ehesp, Irset (Institut de recherche \\ en santé, environnement et travail - Research Institute for Environmental and \\ Occupational Health), UMR_S 1085, F-49000 Angers, France; ${ }^{b}$ ERCOS Research \\ Group (Pôle), Laboratory of ELLIAD-EA4661, UTBM-University of Bourgogne \\ Franche-Comté, 90010 Belfort, France; ${ }^{C}$ ACTÉ, University of Clermont-Auvergne, \\ 63100 Clermont-Ferrand, France \\ *Corresponding author. Tel.: +33787722141; e-mail: mohsen.zare@utbm.fr

\section{Biographical note.}

M. Norval: is a doctor of ergonomics and a lecturer in Ergonomics at the University of Orléans, France. He also intervenes in various industries as ergonomists for the prevention of MSDs.

M. Zare: is an assistance professor in ergonomics at the UTBM in France. His research area is workstation design and MSDs prevention.

R. Brunet: is a lecturer and practitioner in occupational health and ergonomics. He also intervenes in the industries for the prevention of MSDs.

F. Coutarel: is an associate professor of Ergonomics at the University of Clermont-Ferrand. His research area is the prevention of MSDs and workplace intervention.

Y. Roquelaure: is a full professor of Occupational medicine and ergonomics at the University of Angers and head of the ESTER research laboratory. His research area is ergonomics, prevention of MSDs, and epidemiology of MSDs. 


\title{
Contribution of Situational Operational Leeway for Ergonomic Assessment in the Evaluation of Work Situations
}

\begin{abstract}
This study investigates the problems related to identifying MSD risk factors using simple risk assessment tools. The purpose is to study the contribution of situational operational leeway (SOL) indicators as a complementary method to the information provided by simple MSD risk assessment tools and to show how SOL might be a supplement to these established tools.

Eight simple tools (OSHA, RULA, REBA, QEC, CE, EAWS, NIOSH, and MAC) were used to evaluate ten workstations in the metallurgy industry. The indicators of SOL, derived from the human-centred activity model, were also explored in the same workstations to define whether SOL is adequate. The results of these two approaches were compared to identify the difference between them.

Analysing the risk of MSD on ten workstations using eight simple tools showed the variability of exposure between tools for identical work situations. We analysed the same workstations with the SOL indicators, and disagreement was found in judgment between the two approaches of MSD risk identification. The SOL indicators estimated a lower risk of MSD than the simple tools. This study proposes that SOL indicators might improve the phase of MSD risk identification as a complement to the current simple tools.
\end{abstract}

Keywords: Critical situation, risk assessment tool, Musculoskeletal Disorders, Situational Operational Leeway 


\section{Introduction}

Risk prevention approaches for musculoskeletal disorders (MSDs) aim to improve working situations (Aptel, Gerling, and Cail 2000; St-Vincent et al. 2011). In the majority of preventative models, risk evaluation is the first step in MSD risk prevention. This initial assessment phase determines the risk level using simple assessment tools and directs the prevention approach towards the most critical work situations. The most commonly used MSD risk assessment tools are paper-based observational methods, self-reported questionnaires, and in-house methods (G. C. David 2005; Malchaire et al. 2011; Takala et al. 2010). These simple tools identify MSD risk based on characteristics of the work activity. The majority of observational tools evaluate the worker's exposure to MSD risk factors using a checklist. These tools primarily consider a limited number of biomechanical and physiological parameters (G. C. David 2005; Denis, Lortie, and Rossignol 2000; Malchaire et al. 2011). The questionnaire/self-assessment tools gather information on the task and establish a risk level based on the perceptions and feelings of the workers (Descatha et al. 2009; Hansson et al. 2001; Roman-Liu 2014). Large industrial groups have created in-house tools compatible with their specific activity (Berlin et al. 2009; Hägg 2003; Törnström et al. 2008). In-house ergonomic methods often use a triangulation of data that is gathered by observations, questionnaires (asking for the perception of workers), and direct measurements to evaluate risk levels.

Previous studies have criticized the reliability and repeatability of simple tools (Barrero, Katz, and Dennerlein 2009; Chiasson et al. 2012; Zare et al. 2017). The results of these tools have been often questioned because of inter and intra-individual variability, the variations of the technical-organizational system (e.g., unexpected mishaps/incidents arising from machines and materials), and the diversification of products (Badets, Merlo, and Pilniere 2017; Koukoulaki 2014; Mathiassen 2006; Zare, 
Sagot, and Roquelaure 2018). Furthermore, scientific knowledge of the etiological model of MSDs has been gradually expanded, leading to a consensus on the multicausality of MSD risk factors (J. Bodin et al. 2018; Julie Bodin et al. 2017; Karsh 2006; Roquelaure 2018). The variability of activity (e.g., individual variability, production, and organizational variations) and multi-causality of MSDs question the use of simple assessment tools solely in MSD risk estimation. These tools might be little representative of the non-ergonomic situation in a workplace and may not facilitate monitoring and following the effects of changes/interventions on risk exposure.

Following a systematic and developmental approach and focusing not only on the constraints, which simple tools often evaluate, but also on the resources of the work situation provide the possibility for activity regulation (despite the individual, environmental, and organizational constraints). Thus, the activity of the operator is not as simple as applying prescribed instructions but is a regulatory process aimed the achievement of objectives (either personal or set by the company) by managing the system and individual variations (Hubault and Bourgeois 2013; Roquelaure 2018; Sznelwar and Hubault 2015; Daniellou * 2005). The notion of situational operational leeway (SOL) arises from the convergence of the characteristics of a professional environment and those of the worker (Coutarel et al. 2015; Vezina et al. 2016; Coutarel 2004). This merging is entirely situational, and it has been defined as follows:

\footnotetext{
'Situational operational leeway constitutes the possibility for the operator to develop an efficient mode of operation in a specific work situation (or work strategy). "Efficient" meaning effective in the performance of tasks and protecting oneself at work' (Coutarel et al. 2015).

This definition refers to the human-centred activity model (Vézina 2001). Figure 1 shows 46 representative indicators of this model, frequently used for ergonomics interventions (Coutarel, Roquelaure, and Daniellou 2013; St-Vincent et al. 2011; Vézina
} 
2001). We suggest the possibility of using three components of this model for the risk assessment phase: the work strategies developed by individuals to overcome the work constraints, the effects of activity on health and the effects on performance. This approach might respond to the difficulties discussed above regarding the simple MSD risk assessment tools. We assume that using this model to assess MSD risk factors might improve the identification phase of critical situations. The previous study demonstrated that none of the simple tools currently used by companies for MSD risk assessment consider whether SOL is sufficient in a work situation (Norval et al. 2019). Furthermore, these tools do not evaluate the number of operational strategies available to the operator in dealing with a situation in a suitable manner.

This study aims to investigate the contribution of SOL indicators compared to the information provided by simple risk assessment tools and to show how SOL might be a supplement to these tools. The risk of MSDs was measured by eight simple tools and by three components of the SOL. The results were then compared to find the differences between these methodologies to estimate MSD risks.

\section{Material and Methods}

This study was carried out in a French company that produces and assembles diesel engines. The production lines consisted of the main engine parts (i.e., cylinder heads, engine blocks, and connecting rods), a complete engine assembly line, and a trim line. We used eight MSD risk assessment tools and SOL indicators on a sample of ten workstations. These workstations were selected in collaboration with the company's occupational health and safety experts based on the difficulties encountered by workers. Having worked with the company for three years, we had in-depth knowledge of the selected case studies. Before starting the experimentation, the research ergonomist and the operators defined the reference situation for each workstation. The reference 
situation represented the situation most exposed to MSD risks among all the scenarios encountered at the workstation. Each workstation in our sample was firstly evaluated using eight simple tools, and then, the reference situation selected on this workstation was examined by the SOL questionnaire. The ten cases studied correspond to the ten reference situations chosen from ten workstations (Table 1).

The sample consisted of two workstations for rod machining (Connecting rod finishing and Connecting rod drafting), one workstation in the engine painting area (Pre-paintwork covering), four workstations for final engine assembly (Final engine assembly line, Engine wiring unit assembly, Engine injector kit preparation, and Manifold/turbo assembly preparation), one workstation in the engine preparation area before testing (Fixtures/equipment pre-testing), and two workstations in the engine kit preparation area (Preparation of small parts orders and Fixtures packaging). The ten selected workers were experienced operators (having worked at the workstations, at least, for more than six months), without any restriction (incapacity to perform the activity) and volunteered to participate in this study (Table 1). The written informed consent was obtained from all participants. We studied only one operator per workstation because of the industrial restrictions and the qualitative nature of this study.

Each workstation was observed for 2 to 2.5 hours (nine identical cycles separately for each tool) during the evaluation by the simple tools. The first observed cycle on a workstation was recorded, and then the eight other cycles selected for assessments were verified to be as same as possible with the recorded film. SOL indicators were then investigated over 1.5 to 2 hours on ten identical cycles (the same cycles as for the simple tools) using an SOL checklist and interviews with the operators. The parameters for the study, such as the method for selecting the reference situation, 
the assessor, the evaluation tools (simple tools and the SOL questionnaire), and the methodology for approaching the operators were similar for ten workstations.

\section{MSD risk assessment tools}

The following observational methods were used to evaluate MSD risk factors in this study: Occupational Safety and Health Administration (OSHA) checklist (Silverstein 1997), an in-house tool called Ergonomic Criticality (CE), Quick Exposure Checklist (QEC) (G. David et al. 2008), Rapid Upper Limb Assessment (RULA) (McAtamney and Corlett 1993), Rapid Entire Body Assessment (REBA) (Hignett and McAtamney 2000), Ergonomic Assessment Worksheet (EAWS) (Schaub et al. 2013), the revised NIOSH equation (Waters et al. 1993), and Manual handling Assessment Charts (MAC) (Monnington et al. 2003). Table 2 shows the indicators evaluated by each of the selected tools.

The same researcher used eight simple MSD risk evaluation tools, one after the other for each workstation. The worst situation (i.e., the riskiest posture, the highest force exerted, and the more repetitions) was considered as risk factors when a simple tool was applied in a workstation. To compare the results and study their variations, we codified the interpretation scales for all of the tools across three levels: 1. Low-risk situation (acceptable), 2. Moderately risky situation (requires further investigation), and 3. High-risk situation (changes required). Table 3 shows the interpretation scales formulated by the tool developers and the codifying carried out in this study. We used only the whole-body score of the EAWS tool and excluded the score of upper limbs because the whole-body score was more representative of risk factors at the workstations. 


\section{Indicators of situational operational leeway (SOL)}

The assessor interviewed each worker about the three elements of SOL indicators: work strategy, effects on the health and performance (Figure 1; supplementary document 1) to determine whether there was adequate, potentially inadequate, or inadequate SOL. The SOL indicators collected two types of information: semi-quantitative information (a four-level system with ratings of $0-3$; the lowest score being the most detrimental regarding SOL) and qualitative data to investigate the given status in more detail. This information was collected through 12 indicators for the work strategy process, four indicators for effects on health, and three indicators for impact on performance (see supplementary document 1; (Norval et al. 2019).

\section{Semi-quantitative evaluation}

The SOL indicator scores (semi-quantitative data) were transcribed to explore the adequacy of SOL for each of the ten reference situations (Table 4). The total scores were calculated separately for each of three components (the method for score calculation is explained in the supplementary document 2). We created an interpretation scale through three levels (low, moderate, and high) for each of the components based on the distribution of scores to ten reference situations. Given the effective distribution observed across three ranges of fairly distinct scores, we distributed "low," "moderate," and "high" scores in three groups of the same size (Table 4).

The results of the three components provided the general interpretation and classification of SOL for each reference situation:

- Inadequate SOL for a situation where at least one of the SOL components gives a "low" score 
- Potentially inadequate SOL where at least two components give "moderate" scores

- Adequate SOL where at least two components give "high" scores

\section{Qualitative evaluation}

We created a model consisting of three components of SOL (work strategy process, direct effect on health, and performance) to reinforce the conclusions derived from the semi-quantitative data. The qualitative data obtained during the interview using the SOL indicators were transcribed to make the SOL model (figure 2), which provided a close look at the SOL classifications initially obtained from the semi-quantitative data. Company occupational health experts contributed to interpreting the components. The interpretation of each component was carried out based on the expertise of the ergonomists (the knowledge of ergonomist about SOL, population, workstations) and the indices gathered from the qualitative data.

Figure 2 shows an example of the reference situation Unscrewing connecting rods in the Connecting rod finishing workstation. Inadequate SOL is justified in this reference situation because of negative indices identified by three components of SOL. The negative indices observed for the work strategy process component were lack of variations in the work strategies, work pace with highly changeable rhythm (acceleration/deceleration), impossible to do the task in another way, few suggestions for improvements accepted, low levels of exchange between operators about the best practice, and low level of assistance between close colleagues. Regarding the direct effects on health component, intermittent pain and discomfort in the shoulders were identified, and significant fatigue was observed following the implementation of the reference situation. We recognized difficulties in keeping up with the rhythm of work 
pace (feeling of always lagging), baseline productivity sometimes not achieved, and a quantity of negative feedback on the quality of the products produced, which were the negative indices for the direct effects on performance. The same models were created for ten reference situations under study.

A status of inadequate, potentially inadequate or adequate SOL was recorded for each reference situation using three components observed separately:

- Inadequate SOL where three components are negative

- Potentially inadequate SOL where at least one component is negative

- Adequate SOL where three components are positive

\section{Data analysis}

The results of eight simple tools were descriptively analysed to study the difference between tools for risk evaluation in the same workstations. The SOL indicators were analysed with the semi-quantitative data, and a further level of analysis was provided using the qualitative data. The results were qualitatively compared to study the agreement/disagreement between the level of risk assessed by the simple tools and the level of SOL adequacy found by the SOL indicators.

\section{Results}

\section{Simple tools for evaluating MSD risk}

The results of eight simple tools showed the variability between the results of different simple tools (inter-tool variance) for the same workstation (Table 5). The Manifold/turbo assembly preparation workstation was evaluated using ten different tools which gave identical results, while the evaluation of the Connecting rod finishing and Fixtures packaging workstations provided different results from one tool to another. 
Our results showed little variability in the results of the specific tools for manual material handling for six workstations involving manual handling tasks (Table 5).

The variability in the average score of the tools for ten workstations indicated a difference between tools (inter-tool variability). Figure 3 shows the distribution of risk status between low, moderate, and high risk for each simple tool. The OSHA checklist and REBA rendered the highest number of extreme risk situations, with 8 and 6 out of 10 workstations, respectively. The Ergonomic Criticality tool and QEC identified 7 out of 10 workstations as having low-risk status. The NIOSH equation and MAC (tools specific to manual material handling tasks) classified ten workstations as low or moderate risk (Figure 3).

The OSHA checklist resulted in little variance between ten workstations $(\mathrm{SD}=0.3)$, while RULA gave a standard deviation of 0.7 . The results from the NIOSH equation $(\mathrm{SD}=0.3)$ and $\mathrm{MAC}(\mathrm{SD}=0.5)$ also showed the variability between workstations (Table 5).

\section{Investigation of SOL indicators: semi-quantitative and qualitative data}

\section{SOL assessed by the semi-quantitative method}

The results of three components of SOL indicators for each reference situation showed that $50 \%$ of the reference situations had inadequate SOL (Unscrewing connecting rods, Attaching engine to overhead conveyor, Injector assembly, and Equipping engine flywheel pre-testing), 40\% had potentially inadequate SOL (Connecting rod drilling, Top end fitting and connecting, and Installation of turbo onto manifold), and 10\% had adequate SOL (Packaging of a small part). The score of each component of the SOL indicators varies from low to high scores. For example, the reference situation Unscrewing connecting rods for the workstation Connecting rod finishing had 
inadequate SOL. The low score was for the work strategy process and direct effect on performance components, and a moderate score was given for the direct effect on health component (Table 6).

\section{SOL assessed by the qualitative method}

Table 7 presents a summary of the qualitative information used to classify the adequacy of SOL in work situations. Our findings showed inadequate SOL for two reference situations (Unscrewing the connecting rods and Injector subassembly), the possible inadequacy of SOL for four reference situations (Roll top motor covering, Attaching engine to overhead conveyor, Installation of turbo onto manifold, and Fixtures bagging), and the adequacy of SOL for four reference situations (Connecting rod drilling, Top end fitting and connecting, Equipping engine flywheel pre-testing, and Packaging of a small part; Table 7).

For ten reference situations studied, the direct effects on health component had negative consequences for half of the reference situations (five negative statuses) and most influenced on SOL inadequacy. Four negative statuses were found for the work strategy process component and four for the direct effects on performance component.

Comparison between SOL assessed by the semi-quantitative method and the qualitative method

The qualitative data confirms the status given by the semi-quantitative data for five reference situations in our sample. For the other five situations, the qualitative data identified higher SOL adequacy than with semi-quantitative data. We retain the results of the qualitative analysis in case of disagreement between semi-quantitative and qualitative data. We considered that the qualitative results were more precise because they were extracted based on the knowledge of the ergonomist (who observed and analysed the workstations) and the discussion with the operators. 


\section{Comparison between simple tools and the examination of SOL indicators}

Contradictions between the results of the simple tools and SOL indicators were observed in the case of the OSHA checklist, the NIOSH equation, QEC, and REBA, with $90 \%, 84 \%, 80 \%$, and $80 \%$ contradiction, respectively. The least contradictions were observed for the EC, RULA, and EAWS, at $60 \%$. The average contradictions within the results of eight simple tools for evaluating MSD risk and the examination of SOL indicators was $72.6 \%$. Among these differences, $42.6 \%$ of cases had a higher risk with the simple tools compared to the SOL indicators, and 30\% had a lower risk with the simple tools compared to the SOL indicators (Table 8). For example, the OSHA checklist showed eight high-risk stations and two moderate-risk stations, while the SOL indicators showed two situations with an inadequacy, four situations with a possible inadequacy, and four situations with the adequacy of SOL. These results reflect the nonconcordance (90\%) of data and a higher risk estimate with OSHA compared to the SOL examination ( $80 \%$ of contradictions).

\section{Discussion}

\section{Variability of results between simple tools}

This study showed the variability of results between similar simple tools for MSD risk assessment in the same work situation. These results are compatible with the hypothesis that the simple tools might be improved for assessing MSD risks (Bao et al. 2009; Barriera-Viruet et al. 2006; Chiasson et al. 2012; Zare et al. 2017; Zare, Sagot, and Roquelaure 2018). Three factors can explain the variability of results: the nature of the simple tools (e.g., more sensitive to a given situation, the different focus of the theoretical model of each tool, the aetiology of MSDs, low repeatability/reliability of simple tools) (Aptel, Aublet-Cuvelier, and Cnockaert 2002; G. C. David 2005; Malchaire et al. 2011), the criteria related to using these tools (e.g., choice of tool, 
observation period, deployment method, distinguishing the scope of observation, interpretation, and use of results), and the variability of work strategies between operators (different ways of doing an activity by individuals) (Bao et al. 2009; Bourgeois et al. 2006; Gaudez, Gilles, and Savin 2016; Zare, Sagot, and Roquelaure 2018). We observed low variability between the results of the tools specific to manual material handling tasks. The risk factors evaluated by these tools were quite similar between three tools (mostly biomechanical and physical factors), whereas simple observation tools look for slightly varying parameters. Furthermore, the tools specific to manual material handling evaluate one situation, while simple tools evaluate several situations together. Other studies, such as those by Mohammadi et al. (2013), and Kadikon \& Rahman (2016) have reported similar results (Kadikon and Rahman 2016; Mohammadi et al. 2013).

\section{Examinations of SOL indicators}

Although SOL and its link with preventing MSDs have been recognized in the previous literature, practitioners rarely invested in SOL in the workplace (Cuny-Guerrier 2016; Cuny-Guerrier et al. 2015; Lux et al. 2017; Major and Vézina 2015; Vezina et al. 2016). The reason might be that few kinds of literature developed the model or indicators of SOL to encourage ergonomists and practitioners to use the concept of SOL in a real setting. Vézina (2001) created a model of SOL, consisting of five components (Figure 1), for ergonomics intervention. We used three components of this model (work strategy process, direct effect on health, and direct effect on performance) to study the state of SOL adequacy, which allows identification of critical situations for MSDs. We excluded the internal and external determinant components of Vézina's model (Figure 1) because they are unsuitable for recognizing critical situations and risk factors for MSDs. Indeed, an ergonomic analysis of work that identifies the determinants of 
workers' empowerment (Roquelaure 2018) is not the aim of the risk assessment although a few simple tools explore some determinants (Norval et al. 2019).

Considering the activity's determinants implies that we can establish their number and nature from the start, which means taking into account determinants of determinants (which are sometimes remote in time and space); it also means understanding the complex interaction of determinants among themselves and the role and consequences of variability (production and individual) on these determinants. When seeking to identify critical situations, we do not aim to know the extent of SOL (characterized by the complicated relationship between the internal and external determinant and three components of SOL), but the state of SOL adequacy, which makes it possible to limit the consequences of the activity on health and performance (characterized by three SOL components). Determinants of the work situation (internal and external) can be studied during the ergonomic analysis prioritized for improvement in a critical situation.

In this study, we proposed to consider 19 indicators that are representative of three SOL components to complete the exposure evaluation derived from simple tools and understand how individuals encounter the constraints of the work situation. The SOL indicators used (Figure 1) were taken from the study by Norval et al. (2019) and are considered to be representative of work strategy processes and their effects on health and performance (Coutarel 2004; Cuny-Guerrier 2016; Durand et al. 2009; Gouédard and Rabardel 2012; Lux et al. 2017; Major and Vézina 2015; Tomás and Fernandez 2015). The indicators proposed are broad enough to avoid the restriction of the fields of study and to facilitate examination.

SOL exploration was conducted using a semi-quantitative and a qualitative method, which resulted in differing SOL adequacy in five reference situations. The 
contradictions observed can be explained by the accuracy of the examination methods. Although the study of semi-quantitative data reveals a trend relating to the state of SOL adequacy (differences always in the same direction), it seems crucial to take an in-depth look at the trends obtained through qualitative information, which are more accurate, contextual, and interrelated (Hignett * and Wilson 2004; Messing et al. 2005). The most suitable method for studying SOL indicators is analysing the work by combining the qualitative observations (such as auto-confrontation; (Clot et al. 2000)) and discussion with workers (qualitative analyses). This qualitative analysis specifies the detailed information in a multifactorial, systemic, and participatory approach that is consistent with existing literature and the development of etiological models (St-Vincent et al. 2011; Vézina 2001; Hignett and Wilson 2004).

\section{Comparison of simple tools and the examination of SOL indicators}

We found differences in the estimation of MSD risk between the results of simple tools and the state of SOL adequacy. Simple tools tend to estimate the MSD risk to be higher compared to the assessment of SOL adequacy. This finding is consistent with the idea that SOL considers restrictions by integrating the resources of the work activity (Sznelwar and Hubault 2015; Daniellou * 2005). The use of simple tools is based on considering essential constraints (mostly biomechanical factors) in an observation window described as "here and now." SOL, on the other hand, is based on work strategies (a strategy used when encountering the constraints) and the effects of a particular work situation by distinguishing between the workstation and critical situations among all the situations that constitute a workstation (Coutarel, Roquelaure, and Daniellou 2013; Cuny-Guerrier 2016; Vézina 2001). To target critical situations in this study, we distinguish between the workstation and the most critical situations (reference situations), which makes it possible to be more representative than an overall 
view of the exposure in the workstation.

Our results show a lower risk during the SOL examination compared to the results of simple tools. Simple tools mainly studied exposures to the physical risk factors of the activity and direct the users' attention towards specific characteristics of the activity (mainly biomechanical factors) that the tools' developers consider to be the MSD risk factors (Norval et al. 2019). Nevertheless, the work activity mobilizes the individual at all levels (physical, cognitive, subjective, and social, all of which are inseparably linked) and is built within a framework of objectives, constraints, and resources (Coutarel, Roquelaure, and Daniellou 2013; Sznelwar and Hubault 2015). The work strategies studied during SOL examination are the result of the encounter between constraints (environmental, organizational, and individual) and the resources used by the individual to handle the activity and its variabilities (Cuny-Guerrier 2016; Roquelaure 2018). Examples of resources are the possibility of assistance from close colleagues, the possibility of changing the order of tasks, varying one's work strategies, managing the work pace, using the available devices for manual tasks, and changing workstations in the event of pain/discomfort. Furthermore, the development of an efficient work strategy can be dependent on the internal and external determinants (such as individual characteristics, organizational/environmental features). For example, the operator's knowledge of the operation (gained through the experience at a workstation) and the empowerment may arise from being at a company longer might help them to develop strategies for a specific work condition.

Hence why SOL presents results with lower risk compared to simple tools: SOL considers the activity's resources that "compensate" for the constraints. Coutarel et al. (2015) also showed the activity's resources to complement the activity's constraints to prevent MSDs. 
The concept of SOL offers a paradigm shift; it is not "only" to reduce constraints or exposure to specific risk factors, but it also proposes to prevent MSDs by developing the individuals (e.g., expertise, knowledge, self-esteem) through developing their professional activities (e.g., improving one's work strategies, capacity to regulate a task, and possibility of encountering the constraints of work) (Coutarel, Roquelaure, and Daniellou 2013). In this developmental approach, introducing flexible production systems takes priority over introducing systems adapted to a given nominal situation to give resources to the workers' future SOL (Badets, Merlo, and Pilniere 2017; Lux et al. 2017).

\section{Study limitations and perspectives}

This exploratory study has several limitations. The investigation of SOL indicators through other reference work situations (other than the one chosen) may produce different results. Furthermore, SOL was examined through a unique work situationselected by the researcher together with the workers as being the reference situation with the highest risk or with the most constraints among all the situations that comprised the workstation - and only one worker per situation. Studying the more risky situations with several operators might provide the other results and insight our eyes into the different aspects of work activity. We believe that it is more representative to assess the critical situations (most at risk) instead of calculating an average of risks of all the scenarios.

It should be noted that the checklist used to study the SOL adequacy must be validated (repeatability, reliability) if it is to be re-used by occupational safety and health experts in companies. Further study is needed to investigate the suspected role of SOL adequacy in the appearance of MSDs. Another limitation might be related to the focus of different simple tools used. Some simple tools differ in what is evaluated. For 
example, RULA evaluates the upper body, while EAWS and QEC evaluate several body parts, and it would be a source of difference between the results of the various simple tools

\section{Conclusion}

The results of simple MSD risk assessment tools were compared with the state of SOL adequacy. Considering the resources used by workers by work strategy process indicators, combined with information about the effects of activity on health and performance, increases the representativeness of the risk identification phase. The disagreement of results from the simple tools and the SOL examinations showed the importance of suggesting a supplement to the simple tools currently used in companies. This study proposes to improve the quality of risk evaluation and the targeting of critical situations by considering the state of SOL adequacy, which supplements the risk evaluation by simple tools.

\section{Acknowledgments}

The authors would like to thank all the staff of the factory under study (John Deere Orléans-Saran) for their kind collaboration in performing this study. Our special thanks go to the operators who consented to participate in this experimentation. We declare no potential conflict of interest.

\section{Funding}

This work was supported by the French National Research Agency (ANR: Agence Nationale de la Recherche) under Grant [2014/0579]; and John Deere group. 


\section{References}

Aptel, Michel, Agnès Aublet-Cuvelier, and Jean-Claude Cnockaert. 2002. "Les Troubles Musculosquelettiques Du Membre Supérieur Liés Au Travail.” Revue Du Rhumatisme 69 (12): 1181-1190.

Aptel, Michel, Anne Gerling, and François Cail. 2000. "Méthode de prévention. Généralités et principes." Documents pour la médecine du travail 83: 189-194.

Badets, Patrick, Christophe Merlo, and Véronique Pilniere. 2017. "Human Efficiency for Reducing Lean Limits." In 12e Congrès International de Génie Industriel. Compiègne, France. https://hal.archives-ouvertes.fr/hal-01655230.

Bao, Stephen, Ninica Howard, Peregrin Spielholz, Barbara Silverstein, and Nayak Polissar. 2009. "Interrater Reliability of Posture Observations." Human Factors 51 (3): 292-309.

Barrero, Lope H., Jeffrey N. Katz, and Jack T. Dennerlein. 2009. "Validity of SelfReported Mechanical Demands for Occupational Epidemiologic Research of Musculoskeletal Disorders." Scandinavian Journal of Work, Environment \& Health 35 (4): 245.

Barriera-Viruet, Heriberto, Tarek M. Sobeih, Nancy Daraiseh, and Sam Salem. 2006. "Questionnaires vs Observational and Direct Measurements: A Systematic Review." Theoretical Issues in Ergonomics Science 7 (3): 261-284.

Berlin, Cecilia, Roland Örtengren, Dan Lämkull, and Lars Hanson. 2009. "CorporateInternal vs. National Standard-A Comparison Study of Two Ergonomics Evaluation Procedures Used in Automotive Manufacturing." International Journal of Industrial Ergonomics 39 (6): 940-946.

Bodin, J., R. Garlantézec, N. Costet, A. Descatha, J. F. Viel, and Y. Roquelaure. 2018. "724 Validation of a Conceptual Model for Shoulder Pain Risk Factors in Three Independent French Working Populations." Occup Environ Med 75 (Suppl 2): A274-A274. doi:10.1136/oemed-2018-ICOHabstracts. 783.

Bodin, Julie, Ronan Garlantézec, Nathalie Costet, Alexis Descatha, Jean-François Viel, and Yves Roquelaure. 2017. "Risk Factors for Shoulder Pain in a Cohort of French Workers: A Structural Equation Model." American Journal of Epidemiology 187 (2): 206-213.

Bourgeois, F., C. Lemarchand, F. Hubault, C. Brun, A. Polin, J. M. Faucheux, P. Douillet, and C. Albert. 2006. Troubles Musculosquelettiques et Travail. Quand La Santé Interroge l'organisation. Collection. ANACT. Outils et Méthodes. Lyon.

Chiasson, Marie-Ève, Daniel Imbeau, Karine Aubry, and Alain Delisle. 2012. "Comparing the Results of Eight Methods Used to Evaluate Risk Factors Associated with Musculoskeletal Disorders." International Journal of Industrial Ergonomics 42 (5): 478-488.

Clot, Yves, Daniel Faïta, Gabriel Fernandez, and Livia Scheller. 2000. "Entretiens en autoconfrontation croisée : une méthode en clinique de l'activité." Perspectives interdisciplinaires sur le travail et la santé 2 (1). doi:10.4000/pistes.3833.

Coutarel, Fabien. 2004. "La prévention des troubles musculo-squelettiques en conception : quelles marges de manœuvre pour le déploiement de l'activité ?" Phdthesis, Université Victor Segalen - Bordeaux II. https://tel.archivesouvertes.fr/tel-00821248/document.

Coutarel, Fabien, Sandrine Caroly, Nicole Vézina, and François Daniellou. 2015. "Marge de manœuvre situationnelle et pouvoir d'agir: des concepts à l'intervention ergonomique." Le travail humain 78 (1): 9-29. doi: $10.3917 /$ th.781.0009. 
Coutarel, Fabien, Yves Roquelaure, and François Daniellou. 2013. "Le défi ergonomique face aux TMS d'origine professionnelles." In Ergonomie: Travail, Conception, Santé, Octarès, 255-267. A. Drouin. https://halshs.archivesouvertes.fr/halshs-01122119.

Cuny-Guerrier, Aude. 2016. "Régulations et marges de manœuvre situationnelles des encadrants de proximité en sous-traitance : un enjeu de prévention des TMS." Grenoble, France: Grenoble.

Cuny-Guerrier, Aude, Sandrine Caroly, Fabien Coutarel, and Agnès Aublet-Cuvelier. 2015. “Quelle Prévention Des TMS Dans l'activité de l'encadrement de Proximité En Sous-Traitance Interne? Un Cas Dans Le Secteur de La Découpe de Viande." Perspectives Interdisciplinaires Sur Le Travail et La Santé, no. 172.

Daniellou *, François. 2005. “The French-Speaking Ergonomists' Approach to Work Activity: Cross-Influences of Field Intervention and Conceptual Models." Theoretical Issues in Ergonomics Science 6 (5). Taylor \& Francis: 409-427. doi:10.1080/14639220500078252.

David, G. C. 2005. "Ergonomic Methods for Assessing Exposure to Risk Factors for Work-Related Musculoskeletal Disorders.” Occupational Medicine 55 (3): 190199. doi:10.1093/occmed/kqi082.

David, Geoffrey, Valerie Woods, Guangyan Li, and Peter Buckle. 2008. "The Development of the Quick Exposure Check (QEC) for Assessing Exposure to Risk Factors for Work-Related Musculoskeletal Disorders.” Applied Ergonomics 39 (1): 57-69.

Denis, Denys, Monique Lortie, and Michel Rossignol. 2000. "Observation Procedures Characterizing Occupational Physical Activities: Critical Review.” International Journal of Occupational Safety and Ergonomics 6 (4): 463-491.

Descatha, Alexis, Yves Roquelaure, Sandrine Caroly, Bradley Evanoff, Diane Cyr, Jean Mariel, and Annette Leclerc. 2009. "Self-Administered Questionnaire and Direct Observation by Checklist: Comparing Two Methods for Physical Exposure Surveillance in a Highly Repetitive Tasks Plant." Applied Ergonomics 40 (2): 194-198.

Durand, M. J., N. Vézina, R. Baril, P. Loisel, M. C. Richard, and S. Ngomo. 2009. "Margin of Manoeuvre Indicators in the Workplace during the Rehabilitation Process: A Qualitative Analysis." Journal of Occupational Rehabilitation 19 (2): 194-202. doi:10.1007/s10926-009-9173-4.

Gaudez, C., M. A. Gilles, and J. Savin. 2016. "Intrinsic Movement Variability at Work. How Long Is the Path from Motor Control to Design Engineering?" Applied Ergonomics 53 (March): 71-78. doi:10.1016/j.apergo.2015.08.014.

Gouédard, Catherine, and Pierre Rabardel. 2012. "Pouvoir d'agir et Capacités d'agir: Une Perspective Méthodologique?. Illustration Dans Le Champ de La Santé, Sécurité et Conditions de Travail." Perspectives Interdisciplinaires Sur Le Travail et La Santé, no. 14-2.

Hägg, Göran M. 2003. “Corporate Initiatives in Ergonomics - an Introduction.” Applied Ergonomics 34 (1): 3-15.

Hansson, Gert-\AAke, Istvan Balogh, Jeannette Unge Byström, Kerstina Ohlsson, Catarina Nordander, Paul Asterland, Simon Sjölander, et al. 2001.

"Questionnarie versus Direct Technical Measurements in Assessing Postures and Movements of the Head, Upper Back, Arms and Hands." Scandinavian Journal of Work, Environment \& Health, 30-40. 
Hignett *, Sue, and John R. Wilson. 2004. "The Role for Qualitative Methodology in Ergonomics: A Case Study to Explore Theoretical Issues.” Theoretical Issues in Ergonomics Science 5 (6). Taylor \& Francis: 473-493. doi:10.1080/14639220412331303382.

Hignett, Sue, and Lynn McAtamney. 2000. "Rapid Entire Body Assessment (REBA)." Applied Ergonomics 31 (2): 201-205. doi:10.1016/S0003-6870(99)00039-3.

Hubault, François, and Fabrice Bourgeois. 2013. "L'activité, ressource pour le développement de l'organisation du travail." In Ergonomie constructive, 89102. Presses Universitaires de France. https://www.cairn.info/ergonomieconstructive--9782130607489-p-89.htm.

Kadikon, Yusof, and Mohd Nasrull Abdol Rahman. 2016. "Manual Material Handling Risk Assessment Tool for Assessing Exposure To." Journal of Engineering and Applied Sciences 100 (10): 2226-2232.

Karsh, B.-T. 2006. "Theories of Work-Related Musculoskeletal Disorders: Implications for Ergonomic Interventions." Theoretical Issues in Ergonomics Science 7 (1): $71-88$.

Koukoulaki, Theoni. 2014. "The Impact of Lean Production on Musculoskeletal and Psychosocial Risks: An Examination of Sociotechnical Trends over 20 Years." Applied Ergonomics, Advances in Socio-Technical Systems Understanding and Design: A Festschrift in Honour of K.D. Eason, 45 (2, Part A): 198-212. doi:10.1016/j.apergo.2013.07.018.

Lux, Aurélien, Ismail El Mouayni, Bruno Daille Lefevre, Jonathan Savin, Alain Etienne, and Ali Siadat. 2017. "Santé et Sécurité Au Travail: Quatre Approches En Conception Pour Spécifier et Simuler Des Marges de Manoeuvre Pour Les Futurs Opérateurs de Production.” In CIGI2017 12ème Edition Du Congrès International de Génie Industriel, 8p.

Major, Marie-Eve, and Nicole Vézina. 2015. “Analysis of Worker Strategies: A Comprehensive Understanding for the Prevention of Work Related Musculoskeletal Disorders." International Journal of Industrial Ergonomics 48 (July): 149-157. doi:10.1016/j.ergon.2015.05.003.

Malchaire, Jacques, Roland Gauthy, Alain Piette, and Fabio Strambi. 2011. Classification of the Methods for Evaluation and Prevention of Musculoskeletal Disorders. Bruxelles: European Trade Union Institute.

Mathiassen, Svend Erik. 2006. "Diversity and Variation in Biomechanical Exposure: What Is It, and Why Would We like to Know?" Applied Ergonomics, Special Issue: Meeting Diversity in Ergonomics, 37 (4): 419-427. doi:10.1016/j.apergo.2006.04.006.

McAtamney, Lynn, and E. Nigel Corlett. 1993. "RULA: A Survey Method for the Investigation of Work-Related Upper Limb Disorders." Applied Ergonomics 24 (2): 91-99.

Messing, Karen, Ana María Seifert, Nicole Vézina, Ellen Balka, and Céline Chatigny. 2005. "Qualitative Research Using Numbers: An Approach Developed in France and Used to Transform Work in North America." NEW SOLUTIONS: A Journal of Environmental and Occupational Health Policy 15 (3). SAGE Publications Inc: 245-260. doi:10.2190/F2QB-P8YX-MVWU-TYAW.

Mohammadi, Heidar, Majid Motamedzade, Mohammad Amin Faghih, Hadi Bayat, Majid Habibi Mohraz, and Saeed Musavi. 2013. "Manual Material Handling Assessment among Workers of Iranian Casting Workshops.” International Journal of Occupational Safety and Ergonomics 19 (4): 675-681. 
Monnington, S. C., C. J. Quarrie, A. D. Pinder, and L. A. Morris. 2003. "Development of Manual Handling Assessment Charts (MAC) for Health and Safety Inspectors.” In Contemporary Ergonomics, Taylor \& Francis, 3-8. Landon: Paul T.McCabe.

Norval, Maxime, Mohsen Zare, René Brunet, Fabien Coutarel, and Yves Roquelaure. 2019. "Operational Leeway in Work Situations: Do Ergonomic Risk Assessment Tools Consider Operational Leeway for Job Analysis?" International Journal of Occupational Safety and Ergonomics 25 (3). Taylor \& Francis: 429-442. doi:10.1080/10803548.2017.1387392.

Roman-Liu, Danuta. 2014. "Comparison of Concepts in Easy-to-Use Methods for MSD Risk Assessment." Applied Ergonomics 45 (3): 420-427. doi:10.1016/j.apergo.2013.05.010.

Roquelaure, Y. 2018. "1645e Health Promotion and Constructive Ergonomics: An Integrated Developmental Perspective to Improve Sustainable Working Conditions and Well-Being at Work." Occup Environ Med 75 (Suppl 2): A216A217. doi:10.1136/oemed-2018-ICOHabstracts.616.

Schaub, Karlheinz, Gabriele Caragnano, Bernd Britzke, and Ralph Bruder. 2013. "The European Assembly Worksheet." Theoretical Issues in Ergonomics Science 14 (6): 616-639.

Silverstein, B. 1997. "The Use of Checklists for Upper Limb Risk Assessment." In Proceedings of the 13th Triennial Congress of the International Ergonomics Association., 4:109-111. Tampere, Finland.

St-Vincent, Marie, Nicole Vézina, Marie José Bellemare, Denys Denis, Élise Ledoux, and Daniel Imbeau. 2011. L'intervention en ergonomie. Québec: MultiMonde. http://multim.com/titre/?ID=344.

Sznelwar, Laerte Idal, and François Hubault. 2015. "Work Activities as a Resource for Work Organization Design and for Strategic Decisions?" IIE Transactions on Occupational Ergonomics and Human Factors 3 (1). Taylor \& Francis: 37-44. doi:10.1080/21577323.2014.971981.

Takala, Esa-Pekka, Irmeli Pehkonen, Mikael Forsman, Gert- $\backslash A A k e$ Hansson, Svend Erik Mathiassen, W. Patrick Neumann, Gisela Sjøgaard, Kaj Bo Veiersted, Rolf H. Westgaard, and Jørgen Winkel. 2010. "Systematic Evaluation of Observational Methods Assessing Biomechanical Exposures at Work." Scandinavian Journal of Work, Environment \& Health, 3-24.

Tomás, Jean-Luc, and Gabriel Fernandez. 2015. "Du Pouvoir d'agir Aux Marges de Manoeuvre: Une Proposition Pour Le Développement Psychologique Des Gestes." Activités 12 (12-2).

Törnström, Linda, Joakim Amprazis, Marita Christmansson, and Jörgen Eklund. 2008. "A Corporate Workplace Model for Ergonomic Assessments and Improvements." Applied Ergonomics 39 (2): 219-228.

Vézina, Nicole. 2001. "La Pratique de l'ergonomie Face Aux TMS: Ouverture à l'interdisciplinarité." Comptes Rendus Du Congrès SELF-ACE. http://www.academia.edu/download/35036059/v1-05a-vezina.pdf.

Vezina, Nicole, Marie José Durand, Marie-Christine Richard, and Bénédicte Calvet. 2016. "Comprendre La Marge de Manœuvre Situationnelle : Une Question de Retour Durable Au Travail." Archives Des Maladies Professionnelles et de l'Environnement, 34e Congrès National de Médecine et Santé au Travail, 77 (3): 362-363. doi:10.1016/j.admp.2016.03.019. 
Waters, Thomas R., Vern Putz-Anderson, Arun Garg, and Lawrence J. Fine. 1993. "Revised NIOSH Equation for the Design and Evaluation of Manual Lifting Tasks." Ergonomics 36 (7): 749-776.

Zare, Mohsen, Sophie Biau, Rene Brunet, and Yves Roquelaure. 2017. "Comparison of Three Methods for Evaluation of Work Postures in a Truck Assembly Plant." Ergonomics 60 (11): 1551-1563. doi:10.1080/00140139.2017.1314023.

Zare, Mohsen, Jean-Claude Sagot, and Yves Roquelaure. 2018. "Within and between Individual Variability of Exposure to Work-Related Musculoskeletal Disorder Risk Factors." International Journal of Environmental Research and Public Health 15 (5): 1003. doi:10.3390/ijerph15051003. 
Engine

injector kit

preparation

Pre-
paintwork
covering

Final engine assembly line

$\begin{array}{ll}\text { Engine } & \text { Supply harness, } \\ \text { wiring unit } & \text { positioning and screwing, } \\ \text { assembly } & \begin{array}{l}\text { harness connections and } \\ \text { engine casing, visual } \\ \text { inspection }\end{array}\end{array}$

Manifold/ Skid preparation, manifold turbo placement, turbo-manifold assembly preparation assembly, screw and gasket installation, flexible positioning, assembly line preparation

Fixtures/ Fitting/unfitting of engine equipment flywheel and belt, sealing pre-testing and emptying after tests, visual inspection

Preparation of small parts orders

Order taking, parts preparation, packing of parts per unit, put into boxes of six, preparation of kits and shipments

Fixtures Prepare small parts order, packaging e.g., screws for customer shipments, parts and machine preparation, semimanual bagging and order shipping

Mask top engine (upper part)

\section{manual \\ washing}

preparation

Rod drilling

Attachment and motor transfer to overhead conveyor

Connecting harnesses and engine casing

Assembly of Most frequent reference. injector Most constraining

Double turbo installation on the manifold (handling and installation)

Handling and positioning of the engine flywheel

One piece package for kit preparation

Semi-manual bagging (part pick up, deposit in bag and press button closures)
Reference with the most connection tasks.

Reference to anticipate due to being the longest and most demanding task to achieve according to the operator situation according to the operator

Most frequent reference and most demanding operator

Reference with the most high work rate according

Most frequent and highest risk situation according to the operator

Most constraining situation. Most demanding task according to the operator

Most constraining situation. Most

demanding task according to the operator

Most frequently occurring and repetitive situation. Most representative reference according to the operator

Most frequent situation and highest risk reference according to the operator
Manual handling, movement, work rate and management of time spent using machinery, six different references

Very high reference variability, risk of omission or error and increased impact

Trampling, advance bracket spacing (3, 4 and 6cyl), handling height and linked constraining postures

High variability of references, high and variable work rate, a variable number of connections, knowledge of the manufacturing process and production diversity required

The high number of essential tasks, high variation of the work rate stipulated by the assembly line, very high reference variability

Number of essential tasks, very high reference diversities, trampling, high and variable work rate stipulated by the production line

Variable work rate, the variability of references, assisted load handling and equipment, static posture for drilling with vibration

Small and fragile parts, the variability of references, the repetitiveness of movements, autonomy in preparation

Highly repetitive bagging task, a high number of references (screws and gaskets), high work rate and frequency of movements
$\mathrm{T}^{\mathrm{a}}, 25$ years old, $\mathrm{M}^{\mathrm{b}}, 175 \mathrm{~cm}$, $\mathrm{R}^{\mathrm{c}}$, one year in the workstation, one year in the company

T, 28 years old, $\mathrm{M}, 178 \mathrm{~cm}, \mathrm{R}$, one year in the workstation, one year in the company

$\mathrm{P}^{\mathrm{a}}, 41$ years old, $\mathrm{M}, 185 \mathrm{~cm}, \mathrm{~L}$, eight years in the workstation, eight years in the company

$\mathrm{P}, 30$ years old, $\mathrm{M}, 165 \mathrm{~cm}, \mathrm{R}$, six months in the workstation, 11 years in the company

P, 39 years old, $M, 165 \mathrm{~cm}, \mathrm{R}$ one year in the workstation, ten years in the company

$\mathrm{P}, 52$ years old, $\mathrm{F}^{\mathrm{b}}, 164 \mathrm{~cm}, \mathrm{R}$, three years in the workstation, 11 years in the company

T, 20 years old, $\mathrm{M}, 177 \mathrm{~cm}, \mathrm{R}$, seven months in the workstation, seven months in the company

$\mathrm{P}, 54$ years old, $\mathrm{M}, 176 \mathrm{~cm}, \mathrm{R}$, a genetic condition (Forestier's disease), nine years in the workstation, 12 years in the company

$\mathrm{P}, 52$ years old, $\mathrm{M}, 174 \mathrm{~cm}, \mathrm{R}$, two years in the workstation, 11 years in the company

$\mathrm{P}, 53$ years old, $\mathrm{M}, 178 \mathrm{~cm}, \mathrm{R}$, 11 years in the workstation, 14 years in the company

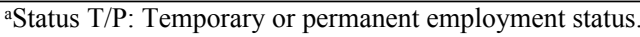

${ }^{b}$ Sex M/F: Male or female sex.

${ }^{\mathrm{C}} \mathrm{R} / \mathrm{L}$ : Right or left hand of dominant use. 
Table 2. Risk factors evaluated by the simple risk assessment tools used in this study

\begin{tabular}{|c|c|c|c|c|c|c|c|c|}
\hline Evaluation tools / Variable & Force & Posture & Duration & Frequency & Load handling & Psychosocial & Operator feeling & Others $^{\mathrm{a}}$ \\
\hline OSHA checklist & $\mathrm{x}$ & $\mathrm{x}$ & $\mathrm{x}$ & & & & & $\mathrm{x}$ \\
\hline Ergonomic criticality & $\mathrm{x}$ & $\mathrm{x}$ & $\mathrm{x}$ & & $\mathrm{x}$ & & $\mathrm{x}$ & $\mathrm{x}$ \\
\hline QEC & $\mathrm{x}$ & $\mathrm{x}$ & & $\mathrm{x}$ & $\mathrm{x}$ & $\mathrm{x}$ & $\mathrm{x}$ & $\mathrm{x}$ \\
\hline RULA & $\mathrm{x}$ & $\mathrm{x}$ & & & & & & \\
\hline REBA & $\mathrm{x}$ & $\mathrm{x}$ & & & & & & \\
\hline EAWS & $\mathrm{x}$ & $\mathrm{x}$ & $\mathrm{x}$ & $\mathrm{x}$ & $\mathrm{x}$ & & & $\mathrm{x}$ \\
\hline Revised NIOSH equation & & $\mathrm{x}$ & $\mathrm{x}$ & $\mathrm{x}$ & $\mathrm{x}$ & & & $\mathrm{x}$ \\
\hline MAC & & $\mathrm{x}$ & $\mathrm{x}$ & & $\mathrm{x}$ & & & $\mathrm{x}$ \\
\hline
\end{tabular}

${ }^{\mathrm{a}}$ Other factors: Gripping, distance carried, precision of activity, nature of the task, working environment, cycle time. 
Table 3. Codification of interpretation scales (three levels system rating) for comparison of results between different tools

\begin{tabular}{|c|c|c|c|c|}
\hline \multirow{2}{*}{ Simple tools } & \multirow{2}{*}{ Interpretation scale provided by tool developer } & \multicolumn{3}{|c|}{ Codification across three levels } \\
\hline & & Low risk (1) & Moderate risk (2) & High risk (3) \\
\hline $\begin{array}{l}\text { OSHA } \\
\text { checklist }\end{array}$ & $\begin{array}{l}<3 \text { : no risk. } \\
<5 \text { : no presumed risk. } \\
\geq 5 \text { : significant risk, occupational medicine must act promptly } \\
>9 \text { : very high risk and immediate action is required }\end{array}$ & $<5$ & $\geq 5$ and $\leq 9$ & $>9$ \\
\hline $\mathrm{CE}$ & $\begin{array}{l}\text { Between } 30 \text { and } 90 \text { roles are considered low risk } \\
\text { Between } 90 \text { and } 112 \text { roles are considered moderately risky } \\
>112 \text { roles are considered high risk }\end{array}$ & $<90$ & $\geq 90$ and $<112$ & $\geq 112$ \\
\hline QEC & $\begin{array}{l}<40 \% \text { : Acceptable level } \\
40-49 \% \text { : Practicable action } \\
49-69 \% \text { : timely action required } \\
>70 \% \text { : Immediate action required }\end{array}$ & $<49 \%$ & $\geq 49$ and $\leq 69 \%$ & $\geq 70 \%$ \\
\hline RULA & $\begin{array}{l}1 \text { and } 2=\text { Acceptable } \\
3 \text { and } 4=\text { Investigate further } \\
5 \text { and } 6=\text { Investigate further and change soon } \\
7 \text { = Investigate and change immediately }\end{array}$ & $\geq 1$ and $\leq 4$ & $\geq 5$ and $\leq 6$ & $\geq 7$ \\
\hline REBA & $\begin{array}{l}1=\text { Negligible risk } \\
2 \text { or } 3=\text { Low risk, take action on confirmation } \\
4 \text { to } 7=\text { Moderate risk, action required } \\
8 \text { to } 10=\text { High risk, short-term action required } \\
11 \text { to } 15=\text { Very high risk, immediate action required }\end{array}$ & $\geq 1$ and $\leq 3$ & $\geq 4$ and $\leq 7$ & $\geq 8$ and $\leq 15$ \\
\hline EAWS $^{\mathrm{a}}$ & $\begin{array}{l}\text { 0-25 points: Low risk, no action required } \\
25-50 \text { points: Potential risk, further investigation needed to evaluate risk. } \\
>50 \text { points: High risk, risk reduction action required }\end{array}$ & $0-25$ points & $25-50$ points & $>50$ points \\
\hline $\begin{array}{l}\text { Revised } \\
\text { NIOSH } \\
\text { equation }\end{array}$ & $\begin{array}{l}<1=\text { acceptable handling } \\
>1=\text { Chronic risk } \\
>3=\text { Acute risk }\end{array}$ & $\leq 1$ & $>1$ and $\leq 3$ & $>3$ \\
\hline MAC & $\begin{array}{l}<7 \text { : Low risk: Examine any of the constituent parts of the activity to reduce risk } \\
\text { Between } 7 \text { and 11: Moderate risk: examine the risk situations and minimize the degree } \\
>11 \text { : High risk: analyze all high-risk situations and lessen the degree }\end{array}$ & $<7$ & $\geq 7$ and $<11$ & $>11$ \\
\hline
\end{tabular}

${ }^{\mathrm{a}}$ Upper limb score of EAWS tool was excluded from the analysis. 
Table 4: The cutoff point for assigning the SOL score for each component. The cutoff point was determined based on the distribution of scores in three groups of the same size

\begin{tabular}{lllll}
\hline Components & Maximum score & Low score & Moderate scores & High scores \\
\hline Work strategy (12 indicators) & 36 & $\leq 20$ & $=21$ & $\geq 22$ \\
Effects on performance (3 indicators) & 9 & $\leq 5$ & $=6$ & $\geq 7$ \\
Effects on health (4 indicators) & 12 & $\leq 5$ & $\geq 6$ and $<11$ & $\geq 11$
\end{tabular}


Table 5. The results of eight simple MSDs risk assessment tools for each workstation

\begin{tabular}{|c|c|c|c|c|c|c|c|c|c|c|c|}
\hline \multirow[b]{2}{*}{ Workstation } & \multirow[b]{2}{*}{ Reference situation } & \multicolumn{7}{|c|}{ Simple observational tools ${ }^{\mathrm{a}}$} & \multicolumn{3}{|c|}{$\begin{array}{l}\text { Manual material } \\
\text { handling tools }\end{array}$} \\
\hline & & $\begin{array}{l}\stackrel{\circ}{\mathscr{D}} \\
\stackrel{\mathbb{P}}{D}\end{array}$ & लि & 帒 & $\underset{\supset}{\stackrel{\Xi}{S}}$ & $\begin{array}{l}\underset{1}{\mathbb{1}} \\
\underset{\supset}{\infty}\end{array}$ & $\sum_{\infty}^{\mathbb{T}}$ & $\begin{array}{c}\text { Final score } \\
\text { of } \\
\text { workstation } \\
\text { mean }( \pm \mathrm{SD}) \\
\end{array}$ & $\begin{array}{l}\text { Zh } \\
\text { On } \\
\underline{W}\end{array}$ & 沗 & $\begin{array}{c}\text { Final score } \\
\text { of } \\
\text { workstation } \\
\text { mean }( \pm \mathrm{SD})\end{array}$ \\
\hline Connecting rod finishing & $\begin{array}{l}\text { Unscrewing connecting } \\
\text { rods }\end{array}$ & 3 & 1 & 2 & 3 & 3 & 3 & $2.5(0.7)$ & 2 & 2 & $2(0)$ \\
\hline Connecting rod drafting & Connecting rod drilling & 3 & 1 & 2 & 3 & 3 & 2 & $2.3(0.7)$ & 2 & 2 & $2(0)$ \\
\hline Pre-paintwork covering ${ }^{\mathrm{b}}$ & Roll top motor covering & 3 & 1 & 2 & 2 & 3 & 2 & $2,2(0.6)$ & 1 & 1 & $1(0)$ \\
\hline $\begin{array}{l}\text { Final engine assembly } \\
\text { line }\end{array}$ & $\begin{array}{l}\text { Attaching engine to } \\
\text { overhead conveyor }\end{array}$ & 3 & 2 & 2 & 2 & 3 & 2 & $2.3(0.4)$ & 1 & 2 & $1.5(0.5)$ \\
\hline $\begin{array}{l}\text { Engine wiring unit } \\
\text { assembly }\end{array}$ & $\begin{array}{l}\text { Top end fitting and } \\
\text { connecting }\end{array}$ & 3 & 2 & 3 & 3 & 3 & 3 & $2.8(0.3)$ & 1 & 2 & $1.5(0.5)$ \\
\hline $\begin{array}{l}\text { Engine injector kit } \\
\text { preparation }\end{array}$ & Injector assembly & 2 & 1 & 2 & 1 & 2 & 2 & $1.7(0.4)$ & 1 & 1 & $1(0)$ \\
\hline $\begin{array}{l}\text { Manifold / turbo } \\
\text { assembly preparation }\end{array}$ & $\begin{array}{l}\text { Installation of turbo onto } \\
\text { manifold }\end{array}$ & 3 & 3 & 3 & 3 & 3 & 3 & $3(0)$ & 1 & 2 & $1.5(0.5)$ \\
\hline $\begin{array}{l}\text { Fixtures / equipment pre- } \\
\text { testing }{ }^{\mathrm{b}}\end{array}$ & $\begin{array}{l}\text { - Equipping engine flywheel } \\
\text { pre-testing }\end{array}$ & 3 & 1 & 2 & 2 & 2 & 2 & $2(0.3)$ & 1 & 1 & $1(0)$ \\
\hline $\begin{array}{l}\text { Preparation of small } \\
\text { parts orders }\end{array}$ & Packaging of a small part & 2 & 1 & 2 & 1 & 2 & 1 & $1.5(0.5)$ & 1 & 1 & $1(0)$ \\
\hline Fixtures packaging ${ }^{\mathrm{b}}$ & Fixtures bagging & 3 & 1 & 3 & 1 & 2 & 1 & $1.8(0.8)$ & 1 & 1 & $1(0)$ \\
\hline Final cores for ten workst & tations mean $( \pm \mathrm{SD})$ & $\begin{array}{l}2.8 \\
(0.3)\end{array}$ & $\begin{array}{c}1.4 \\
(0.6)\end{array}$ & $\begin{array}{c}2.3 \\
(0.4)\end{array}$ & $\begin{array}{c}2.1 \\
(0.7)\end{array}$ & $\begin{array}{c}2.6 \\
(0.5)\end{array}$ & $\begin{array}{c}2.1 \\
(0.5)\end{array}$ & & $\begin{array}{c}1.2 \\
(0,3)\end{array}$ & $\begin{array}{c}1.5 \\
(0.5)\end{array}$ & - \\
\hline
\end{tabular}

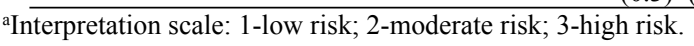

${ }^{b}$ No manual material handling tasks (designated low risk) 
Table 6. Semi-quantitative assessment by SOL indicators for the reference situation of ten workstations

\begin{tabular}{|c|c|c|c|c|c|}
\hline Workstation & Reference situation & $\begin{array}{c}\text { Score work strategy } \\
\text { process }^{\mathrm{a}}\end{array}$ & $\begin{array}{c}\text { Score direct effect on } \\
\text { performance }^{\mathrm{b}}\end{array}$ & $\begin{array}{l}\text { Score of direct effect } \\
\text { on health }\end{array}$ & $\begin{array}{l}\text { SOL adequacy of } \\
\text { situation }^{\mathrm{d}}\end{array}$ \\
\hline $\begin{array}{l}\text { Connecting rod } \\
\text { finishing }\end{array}$ & $\begin{array}{l}\text { Unscrewing connecting } \\
\text { rods }\end{array}$ & 17 (Low) & 3 (Low) & 8 (Moderate) & Inadequate \\
\hline Connecting rod drafting & Connecting rod drilling & 26 (High) & 6 (Moderate) & 11(High) & Adequate \\
\hline Pre-paintwork covering & Roll top motor covering & 22 (High) & 5 (Low) & 11 (High) & Inadequate \\
\hline $\begin{array}{l}\text { Final engine assembly } \\
\text { line }\end{array}$ & $\begin{array}{l}\text { Attaching engine to } \\
\text { overhead conveyor }\end{array}$ & 20 (Low) & 6 (Moderate) & 6 (Moderate) & Potentially inadequate \\
\hline $\begin{array}{l}\text { Engine wiring unit } \\
\text { assembly }\end{array}$ & $\begin{array}{l}\text { Top end fitting and } \\
\text { connecting }\end{array}$ & 21(Moderate) & 9 (High) & 5 (Low) & Inadequate \\
\hline $\begin{array}{l}\text { Engine injector kit } \\
\text { preparation }\end{array}$ & Injector assembly & 16 (Low) & 6 (Moderate) & 4 (Low) & Inadequate \\
\hline $\begin{array}{l}\text { Manifold/turbo } \\
\text { assembly preparation }\end{array}$ & $\begin{array}{l}\text { Installation of turbo onto } \\
\text { manifold }\end{array}$ & 21(Moderate) & 5 (Low) & 11(High) & Inadequate \\
\hline $\begin{array}{l}\text { Fixtures/equipment pre- } \\
\text { testing }\end{array}$ & $\begin{array}{l}\text { Equipping engine } \\
\text { flywheel pre-testing }\end{array}$ & 22 (High) & 6 (Moderate) & 2 (Low) & Inadequate \\
\hline $\begin{array}{l}\text { Preparation of small } \\
\text { parts orders }\end{array}$ & Packaging small parts & 24 (High) & 7 (High) & 10 (Moderate) & Adequate \\
\hline Fixtures packaging & Fixtures bagging & 21 (Moderate) & 5 (Low) & 12 (Low) & Inadequate \\
\hline
\end{tabular}

${ }^{\mathrm{a}} 1$. Low scores $\leq 20 ; 2$. Moderate scores between $=21 ; 3$. High scores $\geq 22$ (maximum score: 36 points).

${ }^{\mathrm{b}} 1$. Low scores $\leq 5 ; 2$. Moderate scores between $=6 ; 3$. High scores $\geq 7$ (maximum score: 9 points).

${ }^{c} 1$. Low scores $\leq 5 ; 2$. Moderate scores between $\geq 6$ and $<11 ; 3$. High scores $\geq 11$ (maximum score: 12 points).

${ }^{\mathrm{d}} \mathrm{SOL}$ is inadequate if at least one column shows a low score; SOL is potentially inadequate if at least the scores of two columns are moderate; SOL is adequate if at least two columns show a high score. 
Final engine assembly line

\begin{tabular}{|c|c|c|}
\hline $\begin{array}{c}\text { Work } \\
\text { Stations }\end{array}$ & $\begin{array}{c}\text { Reference } \\
\text { situation }\end{array}$ & Work strategy process \\
\hline $\begin{array}{l}\text { Connectin } \\
\text { g rod } \\
\text { finishing }\end{array}$ & $\begin{array}{l}\text { Unscrewin } \\
\mathrm{g} \\
\text { connecting } \\
\text { rods }\end{array}$ & $\begin{array}{l}\text { => Negative: } \\
\text { - Lack of variation in the work strategy } \\
\text { - Lack of assistance } \\
\text { - Wide variation in work rhythm }\end{array}$ \\
\hline
\end{tabular}

Connectin
g rod
drafting

=> Positive:

- Several strategies observed Connecting - Steady work rate rod drilling - Assistance

- Several resources for accomplishing the activity

$\Rightarrow>$ Positive:

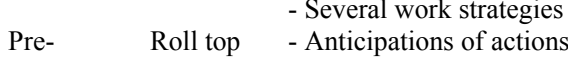

paintwork motor - Steady work rate

covering covering - Assistance,

- The possibility of changing in the event of pain

$\Rightarrow$ Negative:

Attaching - Lack of variability in work strategy

engine to Impossible to change (technique)

overhead - No possibility of changing in the event of pain conveyor - Wide variation in work pace

\section{$=>$ Positive:}

- Several work strategies

Engine Top end - Frequent help and change in the event of pain wiring unit fitting and - Steady work pace (no speeding up/slowing down assembly connecting and individual time management)

\section{- Possibility of changing the order of tasks}

Engine $\quad \Rightarrow$ Negative:

injector kit Injector - Lack of variation in the work strategy

preparatio assembly - Little or no assistance n

Manifold $/ \mathrm{t}$ urbo assembly preparatio n

Fixtures / equipment pre-testing

Installation $\Rightarrow$ Positive:

of turbo - Several work strategies

of turbo - Much assistance
onto

manifold - Steady work pace (individual time management)

- Possibility of changing the order of tasks $\Rightarrow$ Positive:

Equipping - Several work strategies

engine - Steady work pace

flywheel - Assistance

pre-testing - Possibility of changing in the event of pain

- Possibility of changing the order of tasks

\section{Preparatio}

$\Rightarrow$ Positive:

n of small Packaging - Steady work pace (individual time management)

parts

orders

of a small

part

pairs)

- Possibility of changing the order of tasks

- Possibility of changing in the event of pain $\Rightarrow$ Negative:

- Distinct lack of variability of work strategy

Fixtures Fixtures - No assistance

- Impossibility of anticipating or changing the order

packaging bagging of tasks

\section{Direct effects on performance \\ $\Rightarrow$ Negative: \\ - Recurring delays in production \\ - Negative representation of \\ performance \\ - Difficulty in adhering to the cycle \\ time \\ $\Rightarrow$ Positive: \\ - No difficulty achieving the \\ required performance \\ - No delays \\ - Adherence to productivity and \\ quality \\ $\Rightarrow$ Negative:}

- Delay observed at the workstation - Some recurring neck/shoulder pain during several cycle times with the - Fear of forgetting the marouflage, same productions. Risk of forgetting which causes stress

the marouflage

- Poor quality raised by the operator

(marouflage tape)

$=>$ Positive:

$\Rightarrow$ Negative:

- The risk of delay is frequent but - Shoulder/back pain

compensated by the assistance - Severe fatigue

- No quality problems

- Recurring stress according to the operator (many production diversity increase risk of line blockage)

$\Rightarrow$ Positive

$=>$ Positive:

- Little return despite the risk of

- No pain

No discomfort or stress about the

- Recurring delays but very quickly situation

caught up with significant assistance

SOL adequacy $^{\mathrm{a}}$

Inadequate

- No health difficulties

- No pain

Adequate inadequate

\section{$=>$ Negative:}

- Perception of work delays

- Difficulty in following work pace

- Recurring quality problems

\section{$\Rightarrow$ Negative:}

- Some quality problems (missing

clamping or missing piece)

- Recurring delay according to production diversity

$\Rightarrow>$ Positive:

- Slight delay compensated by the assistance

- Productivity and quality by demand

\section{$\Rightarrow$ Positive:}

- No order delay

- Productivity by deman

- A few quality problems (missing part)

$=>$ Positive:

- Highly productive (more than prescribed targets)

No quality problems - A feeling of efficiency by operators
$\Rightarrow$ Negative:

- Pain in several body regions (neck,

shoulder, wrist, upper and lower back) Inadequate related to this work situation

- Stress linked to work pace

$=>$ Positive:

- No pain

- No stress

- Perfect representation of health

Potentially inadequate

$\Rightarrow$ Positive:

- Severe and recurring pain but not related to the actual occupation (pain without relation to the situation)

Adequate

- No stress

- Special attention from management

$\Rightarrow$ Positive:

-Significant recurring pain (without relation to the work situation)

- No stress and a positive representation of work condition

\section{Adequate}

$\Rightarrow>$ Negative:

- Severe pain and fatigue after the observed work situation

- Pathogenic history associated with pain 
Table 8. Agreement/disagreement in the results of simple tools for evaluating MSDs risk and the exploration of SOL (situational operational leeway) indicators from qualitative data

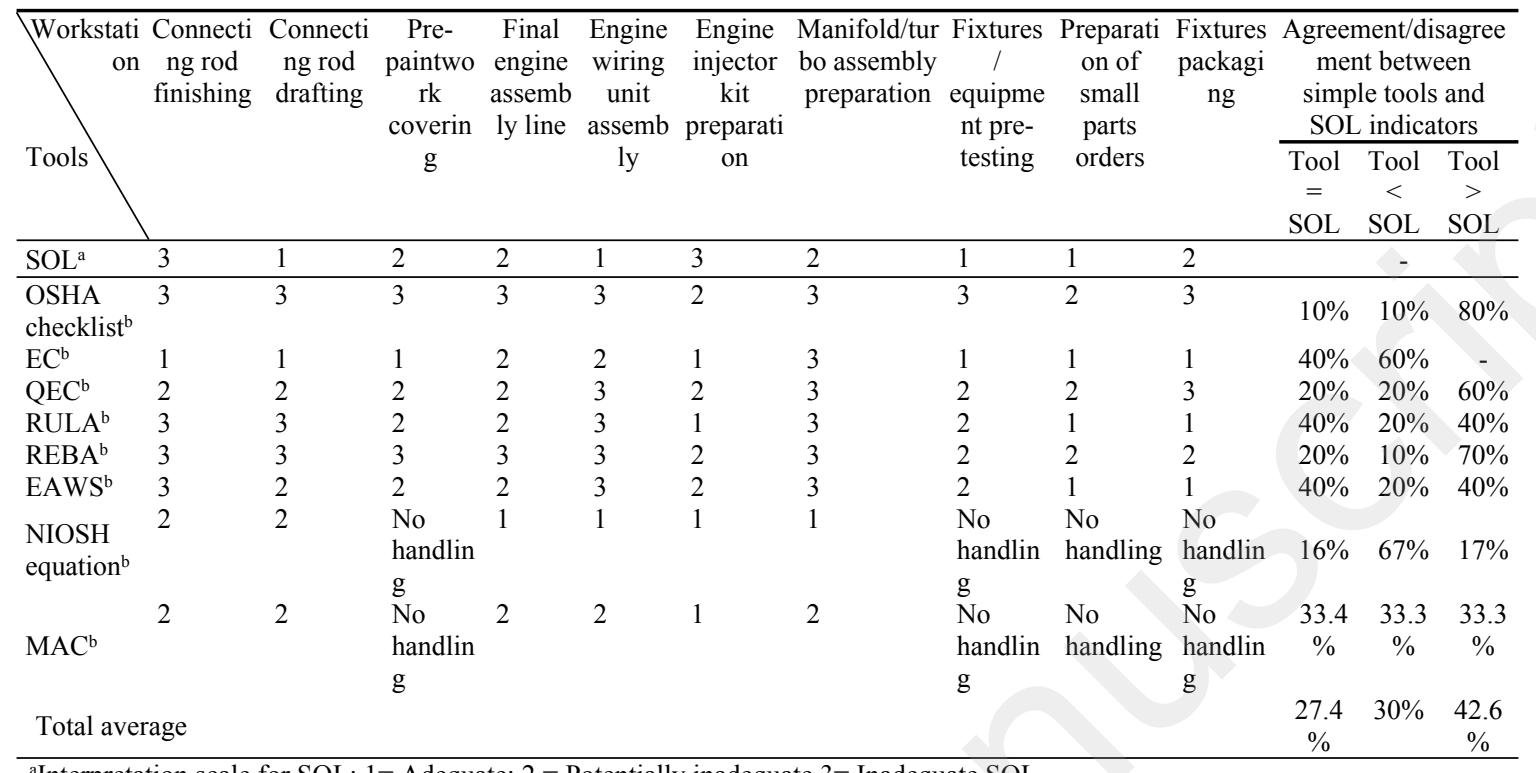

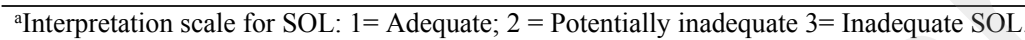

bInterpretation scale for simple tools: $1=$ Low risk; $2=$ Moderate risk; $3=$ High risk. 
Figure 1. Human-centered model of work situations focused on the individuals and their work activity (N. Vézina, 2001). This study focused on 19 indicators of situational operational leeway.

Figure 2. Reconstitution of the three components of SOL indicators for the reference situation of "Connecting rod finishing" (model adapted from N.Vézina, 2001).

Figure 3. Distribution of the number of workstations identified as low, moderate and high-risk status by each simple risk assessment tools 


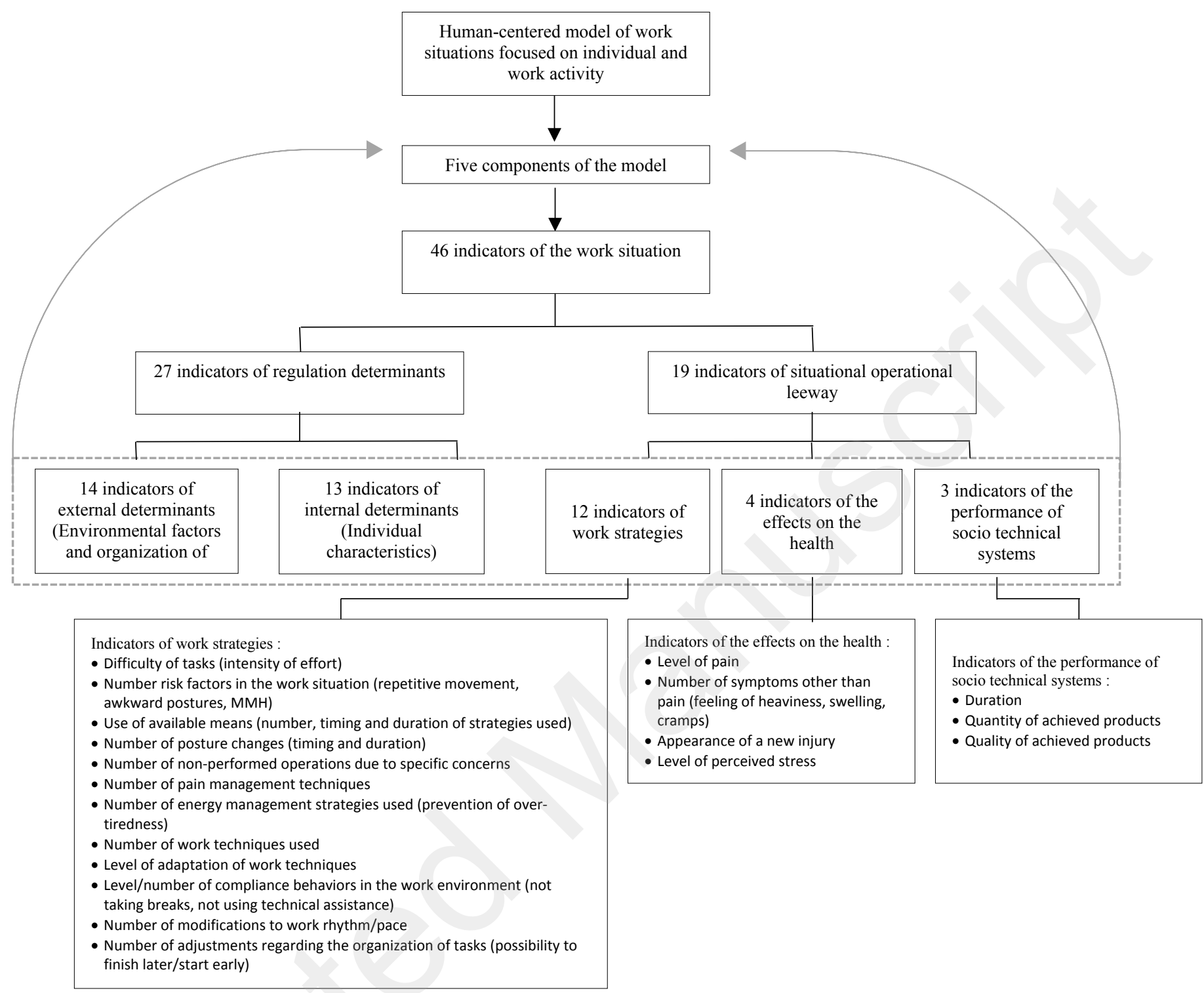

Figure 1. Human-centered model of work situations focused on the individuals and their work activity (N. Vezina, 2001). This study focused on 19 indicators of situational operational leeway. 


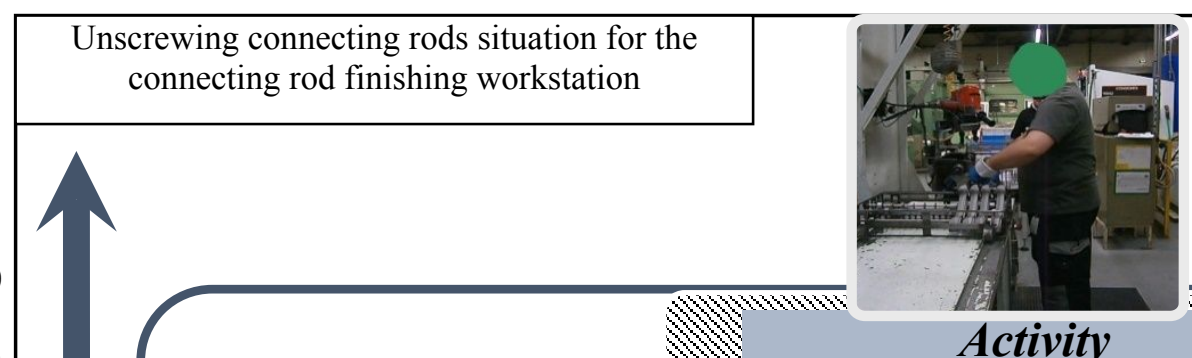

\section{Work strategies process}

- Physical risk factors observed by the ergonomist: many small displacements/movements, awkward wrist posture, wrist effort and reaction/shock from tightening tools, manual material handling (unsafe load weight), repetition, significant physical effort, tool vibration,

- Physical risk factor perceived by the operator: significant physical effort, manual material handling - a weak link with those physical risk factors observed by ergonomists,

- Little change in posture (same movement/cycle),

- Low rate of acceptance of continuous improvement suggestions,

- Action in the reference situation observed was dependent on the activities of the upstream workstation,

- Lack of variation in production strategies*,

- Little variation in production strategies in relation to prescribed tasks,

- Occasional assistance (colleague initiatives)*,

- Lack of technical devices to carry out manual tasks,

- Significant variations in working rhythm (machine fluctuations, delays with the upstream workstation, fixed time management)*,

- Always running behind work (perception of individuals), scant exchange of good practice between colleagues/management,

- Difficult to adjust the order of tasks*

- Obligation to follow the fixed time of machine*

\section{Health}

Recurring pain*: arms/shoulders (weak and transient subsequent to carrying out the observed reference situation).

Significant fatigue* after the reference situation (including numbness).

No absenteeism due to pain, or recognized disease related to the reference situation observed.

Situation has a significant impact on the health of some operators

Stress observed during dialogue*

Figure 2. Reconstitution of the three components of SOL indicators for the reference situation of

"Connecting rod finishing" (model adapted from N.Vézina, 2001).

\section{Performance}

Negative representation regarding productivity issues (some individuals find it difficult to keep up with the pace).

- Negative representation of performance* (feeling of always running behind work and quality deviations).

- Recurring production delays*

- Difficulty in adhering to the cycle time*

\footnotetext{
*The indices used to define the adequacy of SOL for the 3 SOL components.
} leeway
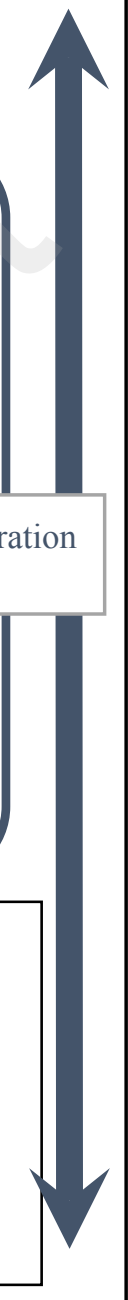
Figure 3. Distribution of the number of workstations identified as low, moderate and high-risk status by each simple risk assessment tools 


\section{supplementary document:}

The distribution of scores for the work strategy component (12 indicators; WS: workstation)

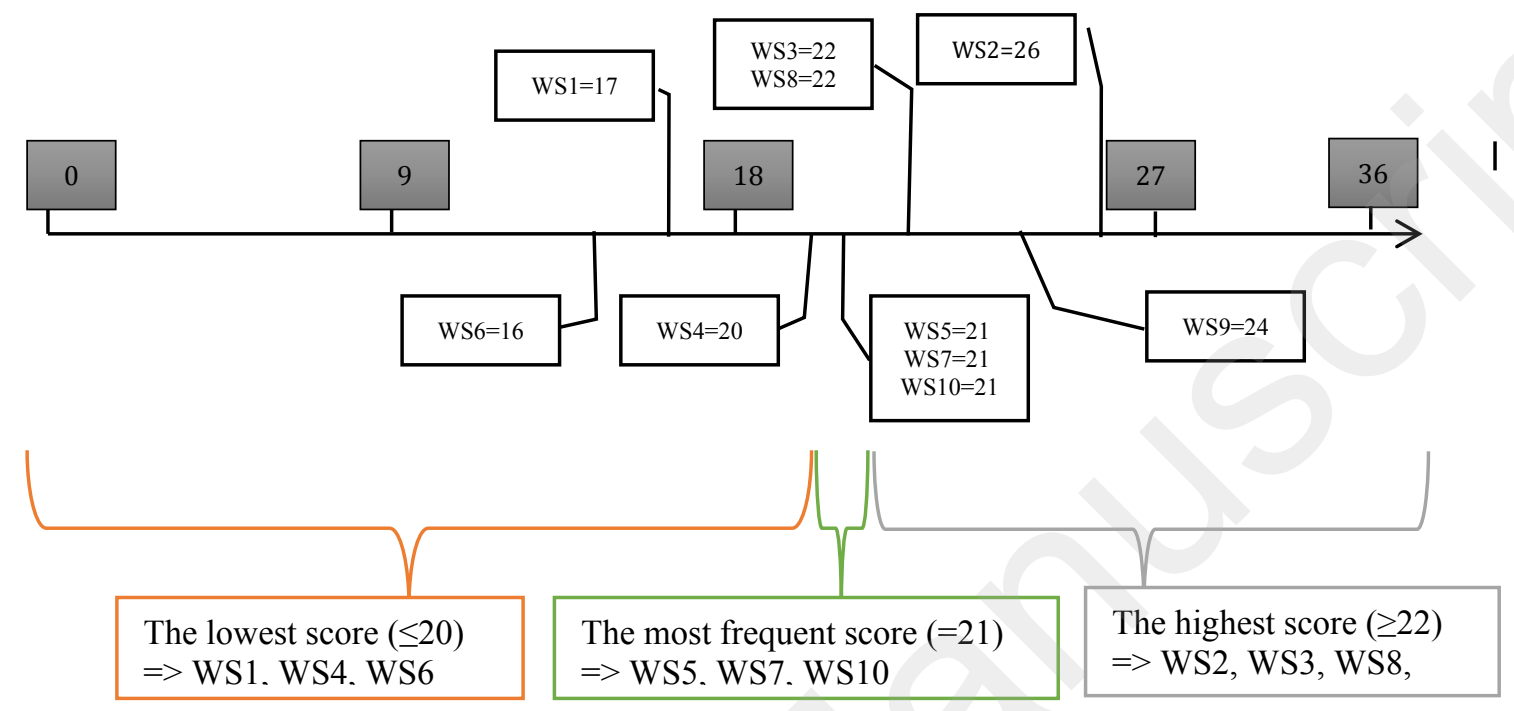

The distribution of scores for effect on performance component (3 indicators; WS: workstation)

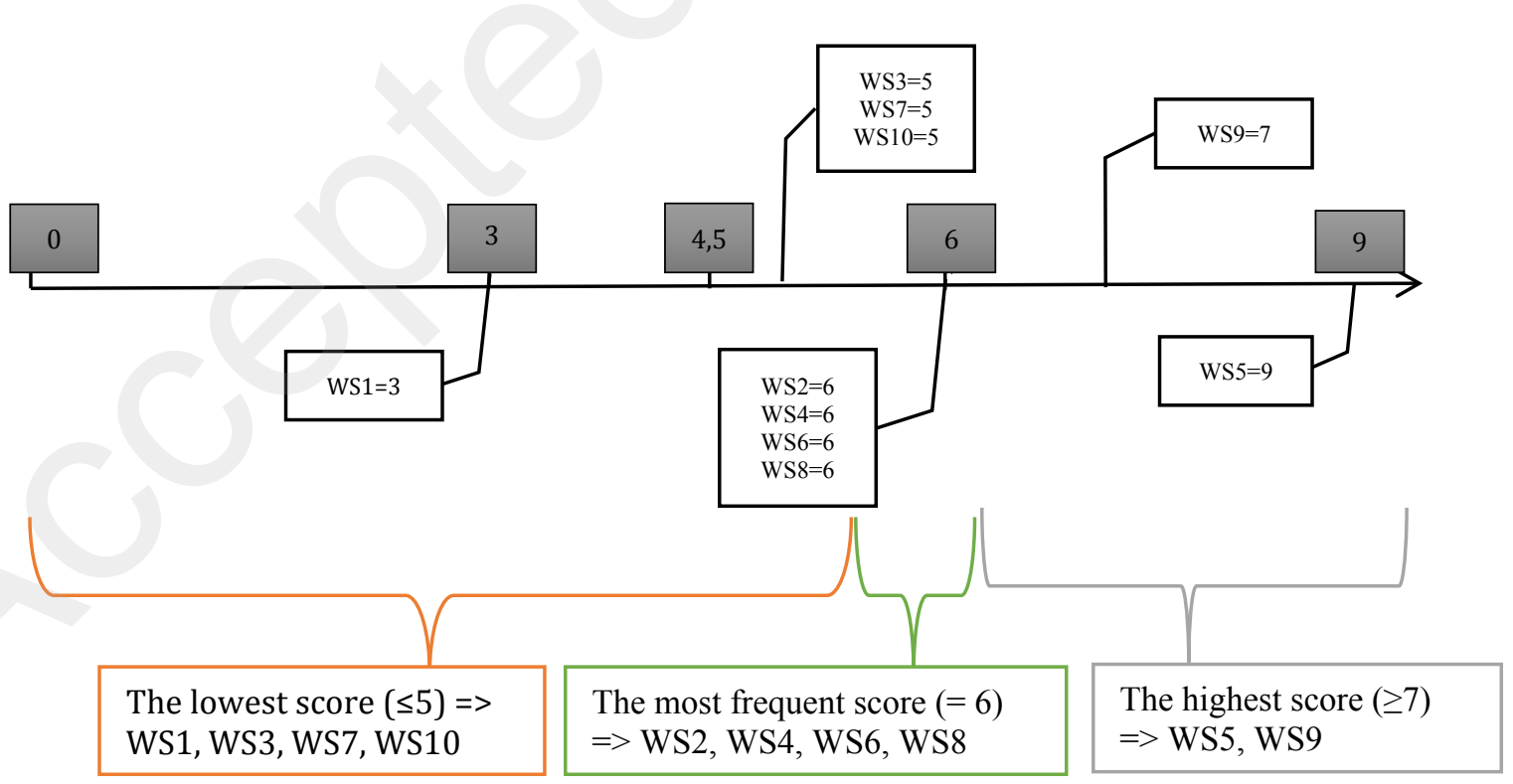


The distribution of scores for effect on health component (4 indicators; WS: workstation)

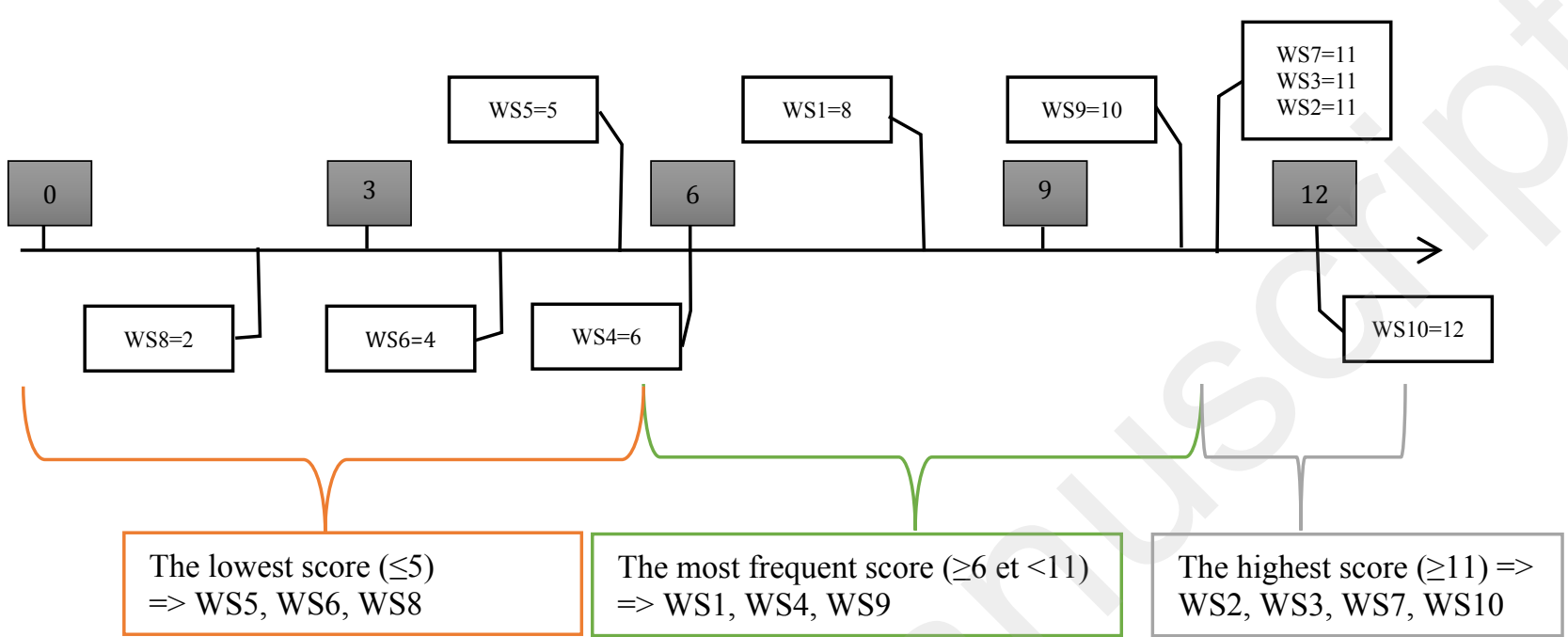

